Article

\title{
Wastewater Biofilm Photosynthesis in Photobioreactors
}

\author{
Antonella Guzzon ${ }^{1}$ (D), Francesca Di Pippo ${ }^{2}$ and Roberta Congestri ${ }^{1, *}$ \\ 1 LBA-Laboratory of Biology of Algae, Department of Biology, University of Rome "Tor Vergata", \\ 00133 Rome, Italy \\ 2 CNR-IRSA, National Research Council, Water Research Institute, Area della Ricerca di Roma 1, \\ 00010 Montelibretti (RM), Italy \\ * Correspondence: roberta.congestri@uniroma2.it; Tel.: +39-06-7259-5989
}

Received: 26 June 2019; Accepted: 8 August 2019; Published: 10 August 2019

check for updates

\begin{abstract}
Photosynthetic performance of algal-bacterial biofilms from an Italian wastewater treatment plant was studied in a flow-lane photobioreactor at different irradiances, temperatures, and flow regime to evaluate the effects of these environmental parameters on biofilms' functioning, in view of application of these communities in wastewater biological treatment. Pulse amplitude modulated fluorescence was used to estimate the effective quantum yield of PSII $\left(\Delta F / F_{m}{ }^{\prime}\right)$ of the light-acclimated biofilms and to perform rapid light curves (RLCs) for the determination of the photosynthetic parameters (rel.ETR $\max , \alpha, \mathrm{I}_{\mathrm{k}}$ ). Chl $a$, ash free dry weight (AFDW), and dry weight (DW) were measured to assess phototrophic and whole biofilm biomass development over time. From the analysis of photosynthetic parameter variation with light intensity, temperature and flow rate, it was possible to identify the set of experimental values favoring biofilm photosynthetic activity. Biomass increased over time, especially at the highest irradiances, where substrata were fastly colonized and mature biofilms developed at all temperatures and flow conditions tested.
\end{abstract}

Keywords: phototrophic biofilm; wastewater; photosynthesis; photobioreactor; Pulse Amplitude Modulated fluorescence; biofilm biomass

\section{Introduction}

Biological treatment is an important and integral part of wastewater treatment (WWT) procedures. Currently, the activated sludge process is the most commonly applied biological WWT technology. The activated sludge treatment utilizes dense bacterial suspended communities, forming biological flocs, to degrade organic material under aerobic conditions [1]. Although this technology provides satisfactory pollutant removal, it requires complex and multistep recycles of activated sludge to meet the limits imposed by environmental regulations. The overall increase of process costs, complexity, and energy input has led, in the last years, to explore more sustainable approaches [2,3]. Thanks to the synergistic relationship between photosynthetic and heterotrophic microorganisms, the use of microalgal-bacterial consortia in WWT is now considered a cost-effective, efficient, and sustainable alternative to conventional activated sludge treatment, especially for municipal wastewaters, due to the potential for cost-free oxygenation, efficient nutrient removal, and carbon dioxide sequestration provided by microalgae metabolism [4,5]. In this way, microalgal-bacterial combinations have been employed for treating secondary wastewater effluents in the form of suspensions in the enhanced pond and wetland (EPW) system, a multiple step process including high-rate algal ponds (HRAPs) [6], and gravity algal harvesters (AHs) [7]. Alternatively, microalgal-bacterial consortia have been grown as attached communities in algal turf scrubbers (ATSs) [8], coupled to constructed wetlands [9] or as 
microalgal-integrated fixed film activated sludge (MAIFAS), an advanced biological WWT process that integrates distinct algal and nitrifying biofilm carriers within conventional activated sludge [10].

Although the complex interactions between microalgae and bacteria in WWT are not yet fully elucidated, outputs of many studies conducted to date have suggested that microalgae, through photosynthesis, provide oxygen to heterotrophic bacteria to reduce chemical oxygen demand (COD). On the other side, bacteria release carbon dioxide and mineral nutrients from respiration and organic matter degradation which are efficiently converted into biomass by microalgae when exposed to solar light in outdoor systems [2,4,11,12]. Simultaneously, the exchange of metabolites results in an overall increase in biomass productivity and hence, pollutant removal efficiency. Moreover, WWT based on microalgae-bacterial consortia has the added benefits to allow for nutrient recover and biomass recycle into valued compounds as fertilizers, growth enhancers, aquaculture feeds, and/or bioenergy, also implementing a biorefinery approach of the biomass produced starting from wastewaters and up-cycling of the effluent water [13-15]. The use of municipal wastewaters as a source of nitrogen and phosphorus to feed the algae is also important for reducing the cost of culturing biomass destined for commercial purposes, such the extraction of biocompounds [16]. In this context, the use of phototrophic biofilms, attached matrix-enclosed microbial communities comprising both phototrophs and chemotrophs, can offer an additional advantage over HRAPs, in terms of time and cost savings involved in biomass accumulation and harvesting. Biofilm indeed is easily removed by scraping it off from the growth support. Moreover, an effluent with a lower total suspended solids concentration is produced with respect to suspended growth systems [12,17-20]. Despite the favorable outlook of wastewater fed biomass production, routine large-scale application of benthic photosynthetic communities in WWT treatment systems is not efficiently exploited, with much effort put on research only at the laboratory and/or pilot scale $[2,21]$. Phototrophic biofilm efficiency in wastewater treatment depends on biomass development and physiology, including photosynthetic activity [22]. Although studies have addressed the potential of nutrient removal from wastewaters [23-26] and the intracellular accumulation by aquatic phototrophic biofilms [27], few have investigated photosynthetic performance and evaluated the environmental factors influencing the process, i.e., geographical location, temperature and oxygen accumulation, light availability, light-dark cycle, as well as $\mathrm{pH}$ variation with photosynthesis.

Therefore, understanding the overall community photosynthesis and photoacclimation capability is pivotal to the exploitation of phototrophic microbial consortia in biological treatment of wastewaters.

Different approaches have been applied to measure photosynthesis of aquatic phototrophic biofilms, such as oxygen microelectrodes, photosynthetic chambers in combination with oxygen probes, and pulse amplitude modulated (PAM) fluorimetry [28-35]. The fluorescence method is advantageous for estimating the rates of photosynthesis for intact biofilms being rapid and non-destructive, as measurements are performed in a shorter time than conventional methods and without the need to remove the phototrophs from the substrata [32]. Moreover, the parameters measured allow insight into key aspects of photosynthetic light capture and electron transport [36].

Accordingly, the aim of this study was to investigate the photosynthetic behavior, biomass development, and production of phototrophic biofilms collected from an Italian WWT plant and cultured in a flow-lane incubator system at different abiotic conditions. Species composition, matrix characterization and nutrient removal capability of these autotrophic-heterotrophic cultured biofilms have been previously investigated [27,37-40]. Therefore, the present work provides additional useful insights into phototrophic biofilms functioning, thus increasing the knowledge of how these complex autotrophic-heterotrophic consortia behave at different environmental factors, in view of their exploitation in wastewater bioremediation. 


\section{Materials and Methods}

\subsection{Biofilm Sampling and Setup of Biofilm Cultures}

Biofilm samples were collected by scraping off the overflow system of the sedimentation tank (ST) of an Italian wastewater treatment plant (WWTP) located in Fiumicino (Rome, Italy). Taxonomic assessment of in situ consortia can be found in [41-45]. The plant is designed to serve the Airport "Leonardo da Vinci" and receives municipal wastewater with an estimated capacity of $6000 \mathrm{~m}^{3}$ sewage per day. Physico-chemical characteristics of the plant have been previously described [41,46].

After sampling, ST biofilm biomass was subjected to a pre-treatment to obtain safe-handling and homogeneous inocula according to [43]. Briefly, scrapings were washed in $2 \%$ sodium hypochlorite for 15 min to eliminate macro- and microzoobenthos and then rinsed in BG11 medium [47] modified for ensuring balanced algal growth by adding vitamins and silicates for diatoms. Moreover, $\mathrm{NO}^{-}$ and $\mathrm{PO}^{-}$concentration was modified to approximate wastewater levels. Thereafter, biofilms were homogenized and frozen at $-20{ }^{\circ} \mathrm{C}$ for $24 \mathrm{~h}$ to remove grazers [43]. To start the cultures, $100 \mathrm{~mL}$ of cell suspension was made up to $4 \mathrm{~L}$ with the modified BG11 and filtered through a $300 \mu \mathrm{m}$ net.

The resulting mixture was inoculated in a semi-continuous flow-lane incubator system (PBI) [48]. PBI contained four separate light chambers (LCs) $(120 \times 10 \mathrm{~cm}$ each) (Figure 1a).

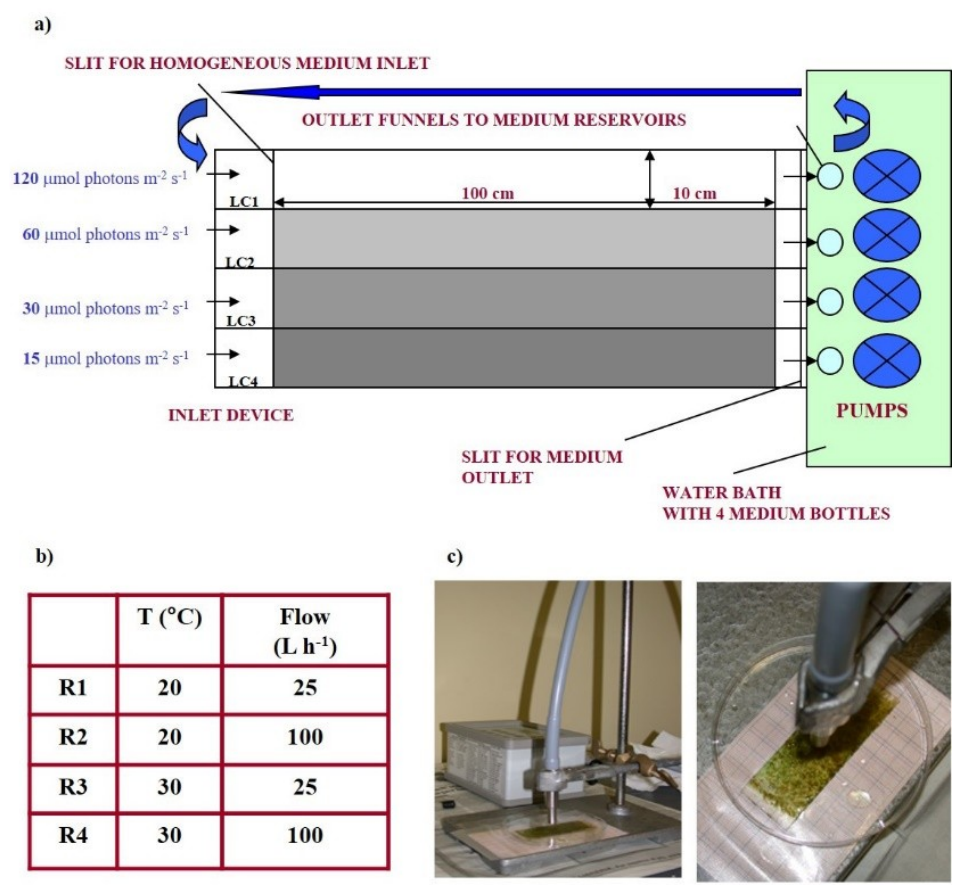

Figure 1. Schematic view of the prototype incubator: In and outlet, light chambers with separator walls for medium guidance, illuminated at four different irradiances (a). Experimental conditions of the four runs performed (b). MINI-PAM used to perform fluorescence measurements on biofilms colonizing the slides in the incubator with the fiberoptic positioned above biofilm surface (c).

Medium flowed above polycarbonate slides $(76 \times 25 \times 1)$, used as substratum for biofilm growth, and was changed at regular intervals (twice per week). Flow rate was valve-regulated. "True light" (T-8, Auralight, Sweden) lamps were used as the light source.

Biofilms were cultured at four photon flux densities (PFDs): $120 \mu \mathrm{mol}$ photon $\mathrm{m}^{-2} \mathrm{~s}^{-1}$ (LC1), $60 \mu \mathrm{mol}$ photon $\mathrm{m}^{-2} \mathrm{~s}^{-1}$ (LC2), $30 \mu \mathrm{mol}$ photon $\mathrm{m}^{-2} \mathrm{~s}^{-1}$ (LC3), $15 \mu \mathrm{mol}$ photon $\mathrm{m}^{-2} \mathrm{~s}^{-1}$ (LC4). Two temperatures $\left(20^{\circ} \mathrm{C}\right.$ and $\left.30{ }^{\circ} \mathrm{C}\right)$ and two flow conditions $\left(25 \mathrm{~L} \mathrm{~h}^{-1}\right.$ and $\left.100 \mathrm{~L} \mathrm{~h}^{-1}\right)$ were tested. These four incubator experiments were referred to as "Runs" (Figure 1b). Transmittance was measured in each chamber by nine subsurface light sensors located under the growth surface. Growth of the biofilm could be accurately tracked by the reduction in light transmittance. The incubator design was 
previously described [48]. All light and temperature sensors were connected to a computer through a serial port for continuous data monitoring and acquisition [48].

Biofilms were sampled at three stages of development as function of biofilm light absorbance values (Absorbance $=100 \%$-percent transmitted light value):

(1) Initial (in), when the average value of absorption was 10\%;

(2) Active (ac), when mean value was $50 \%$;

(3) Mature (ma), at 90-95\%.

Each run lasted $\sim 30$ days. On the last day, biofilm was collected without regard of light absorption and labelled as last sampling (ls).

\subsection{PAM Measurements of Photosynthetic Parameters}

Photosynthetic parameters of cultured biofilms were assessed at each sampling stage using a miniaturized pulse amplitude modulated (Mini-PAM) fluorometer, coupled to WinControl Software (Walz GmbH, Effeltrich, Germany) for computer control and data analysis. In the Mini-PAM, fluorescence was excited by pulses ( $3 \mu \mathrm{s}$ width) of measuring red light from a light-emitting-diode (LED) with the peak excitation band at $650 \mathrm{~nm}$. Fluorescence measurements were performed on light-acclimated biofilms to assess the effective quantum yield of charge separation in photosystem II PSII, either under the incubator light conditions or during the measurement of electron transport rate versus irradiance (ETR/I) curves. Three slides were sampled in the middle of light period ( $8 \mathrm{~h} \mathrm{ca}$.) at the initial stage of biofilm development, immersed in culture medium to avoid desiccation, inhibition of photosynthesis, and/or damage to photosystems, and positioned on a specifically designed grid so that biofilm surface could be virtually divided into 27 spots $(8 \times 8 \mathrm{~mm}$ each). The fiberoptic was kept at $10 \mathrm{~mm}$ above biofilm surface using a holder to obtain a homogeneous field of illumination (Figure 1c). After PAM measurements, the slides were put back in the same position in the light chamber and then re-used for fluorescence assessment in the following samplings, i.e., at the active and mature stage of biofilm development.

The effective quantum yield of charge separation in PSII $\left(\Delta \mathrm{F} / \mathrm{F}_{\mathrm{m}}{ }^{\prime}\right)$ of the light-acclimated biofilms was calculated according to [49] the following:

$$
\Delta \mathrm{F} / \mathrm{F}_{\mathrm{m}}{ }^{\prime}=\left(\mathrm{F}_{\mathrm{m}}{ }^{\prime}-\mathrm{F}\right) / \mathrm{F}_{\mathrm{m}}{ }^{\prime}
$$

where $\mathrm{F}$ is the steady-state fluorescence of the light-adapted sample and $\mathrm{F}_{\mathrm{m}}{ }^{\prime}$ is the maximum light-adapted fluorescence after the application of a single saturating light pulse $(800 \mathrm{~ms}, 3000 \mu \mathrm{mol}$ photon $\mathrm{m}^{-2} \mathrm{~s}^{-1}$ ) $[49,50] . \Delta \mathrm{F} / \mathrm{F}_{\mathrm{m}}{ }^{\prime}$ was measured on 27 spots of three slides (81 replicates) to take into account the heterogeneity of microalgal distribution. Thereafter, ETR/I curves were recorded on three spots on each slide providing nine replicates for each sampling. The position of the spots was chosen randomly at the initial sampling and then kept constant in the active and mature phase. ETR/I curves were measured by exposing the sample to eight increasing PFDs, up to $720 \mu \mathrm{mol}$ photon $\mathrm{m}^{-2} \mathrm{~s}^{-1}$. Each period of actinic light lasted $10 \mathrm{~s}$ before the saturation pulse was applied to determine $\Delta \mathrm{F} / \mathrm{F}_{\mathrm{m}}{ }^{\prime}$. The internal halogen lamp $(20 \mathrm{~W})$ of the Mini-PAM served as light source for saturation pulse and for continuous actinic illumination. The photosynthetic electron transport rate (ETR) between PSII and PSI was calculated from the estimate of $\triangle \mathrm{F} / \mathrm{F}_{\mathrm{m}}{ }^{\prime}$ at different PFDs in actinic light according to the expression:

$$
\mathrm{ETR}=\Delta \mathrm{F} / \mathrm{F}_{\mathrm{m}}{ }^{\prime} \cdot \mathrm{PFD} \cdot 0.5 \cdot \mathrm{a}^{*}{ }_{\mathrm{PSII}},
$$

where 0.5 accounts for the excitation of both PSII and PSI and $\mathrm{a}^{*}$ PSII is the optical cross section of PSII. Since we could not measure $\mathrm{a}_{\mathrm{PSII}}$, relative ETR was calculated as $\Delta \mathrm{F} / \mathrm{F}_{\mathrm{m}}{ }^{\prime} \cdot \mathrm{PFD} \cdot 0.5$.

The ETR/I curves were fitted by means of an automatic spreadsheet based on linear regression for estimating ETR per light intensity and a chi-square minimization for the exponential function ETR $=\operatorname{ETR}_{\max }\left(1-\mathrm{e}^{-\alpha I \text { ETRmax }}\right)$ [51]. From the fit of the maximum rate of relative ETR (rel.ETR $\left.R_{\max }\right)$, the 
initial slope, i.e., photosynthetic efficiency $(\alpha)$ and the light saturation parameter $\left(\mathrm{I}_{\mathrm{k}}=\right.$ rel.ETR $\left.\max / \alpha\right)$ were calculated.

\subsection{Biomass Estimation}

Phototrophic biomass was assessed by determining chlorophyll $a$ concentration per unit area $\left(\mathrm{mg} \mathrm{m}^{-2}\right)$. Chlorophyll $a$ was extracted overnight in $90 \%$ acetone and then quantified spectrophotometrically [52].

Biomass productivity was determined as dry weight $\left(\mathrm{DW} \mathrm{g} \mathrm{m}^{-2} \mathrm{~d}^{-1}\right)$ by oven drying samples at $60{ }^{\circ} \mathrm{C}$ for $72 \mathrm{~h}$. Samples were then burnt at $500{ }^{\circ} \mathrm{C}$ for $1 \mathrm{~h}$ to determine organic biomass (phototrophs + heterotrophs) as ash-free dry weight (AFDW) per unit area $\left(\mathrm{mg} \mathrm{m}^{-2}\right)$ [53].

\subsection{Data Elaboration}

To test the influence of the experimental conditions and their interactions on all biofilm photosynthetic parameters, the standard ANOVA provided by the Past software (v 3.2.5) was used in combination with the Tukey Honestly Significant Difference (HSD) test for multiple post-hoc testing or Mann-Whitney test. The effect of these environmental conditions on initial and latest phases of biofilm development was evaluated by repeated ANOVA. Correlation between Chl $a$ and AFDW was assessed by applying the Spearman's rho-statistic [54].

\section{Results and Discussion}

\subsection{Biofilm Growth}

Biofilm development in the microcosm was monitored through an online and automatic system that continuously recorded the light transmitted through biofilm thickness over experimental time, allowing the calculation of absorbance and the subsequent construction of growth curves $[40,55]$. Growth of biofilms was witnessed by the increasing light absorbance (Figure 2).

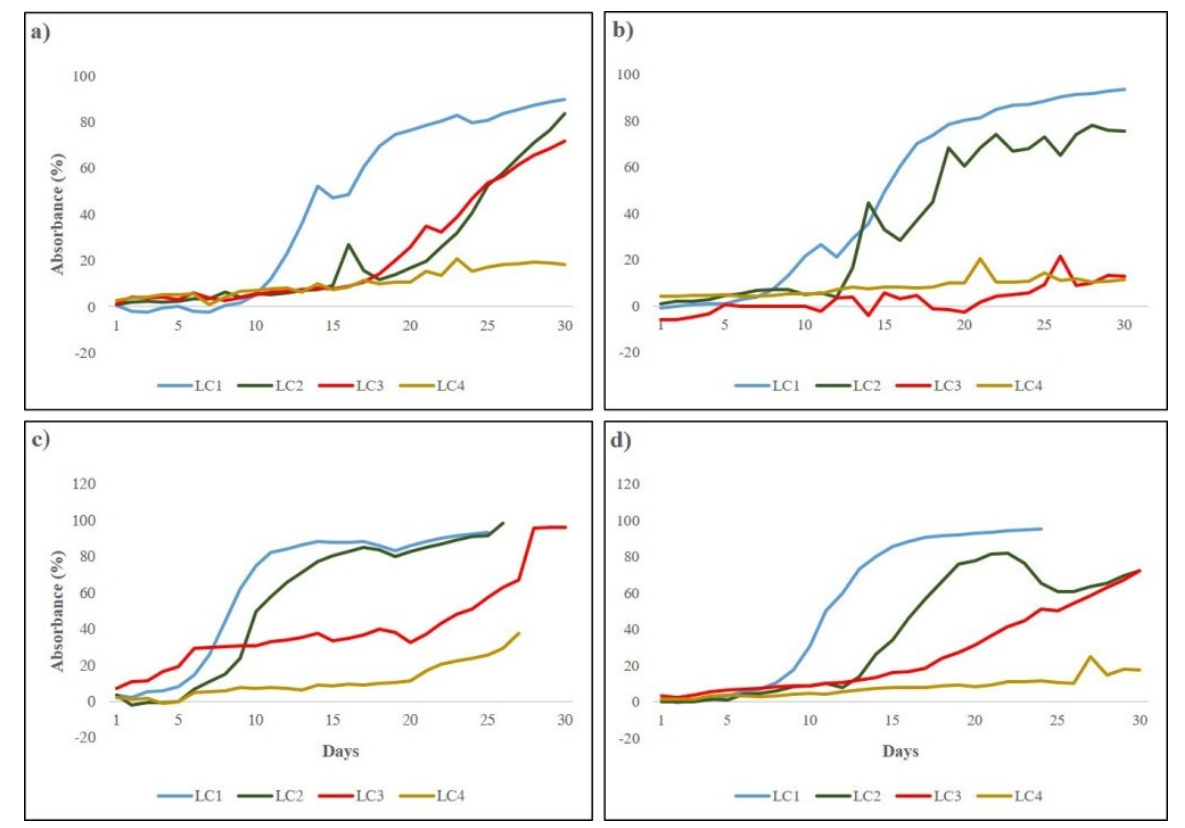

Figure 2. Growth curves of LC1, LC2, LC3, and LC4 biofilms in Run1 (a), Run2 (b), Run3 (c), Run4 (d) obtained by transforming the on-line recorded light transmitted values in light absorbance.

A sigmoidal trend was observed for biofilms grown at the higher irradiances (LC1 and LC2) in all runs, diversely from most of the cultures under lower irradiances (LC3 and LC4) that reached only the initial and active phase. Initial phase lasted between 7 (LC1 Run3) and 14 days (LC2 Run1) for high 
light cultures and between 18 (LC3 Run1, LC3 Run4) and 30 days (LC4 Run4) for the low light ones. Irradiance appeared to influence biofilm development, in particular the duration of the initial phase, i.e., the higher the irradiance, the shorter resulted the lag phase. This is more evident in LC1 cultures, likely due to the dominance of unicellular green algae which have higher growth rates [40]. The slope of the curves, reflecting the active phase of biofilm development, was more pronounced in LC1 and LC2 cultures irrespective of the different temperature and flow conditions tested, reflecting the fast growth of phototrophs. In LC3 and LC4, the active phase was not completed except for LC3 biofilms in Run3 (Figure 2c). Complete development of a mature community was obtained only in cultures at $120 \mu \mathrm{mol}$ photons $\mathrm{m}^{-2} \mathrm{~s}^{-1}$ (LC1) in all runs when biofilms were dominated by filamentous cyanobacteria [40] able to produce high amounts of exopolysaccharides [38], allowing the establishment of complex and structured mature communities. The highest light intensity tested appeared to be the most favorable for biofilm formation and development as the lag phase was shorter, the active growth phase was fast, and mature communities were formed in all runs within the experimental time.

When observed at the macroscopic level, biofilm biomass accumulation on the slides was patchy at the initial phase of development reflecting the adhesion of the pioneer microorganisms during the colonization process [37]. The following active phase was characterized by an increasing and more homogeneous coverage of the substrata which ended to be completely colonized in the mature stage (Figure 3).

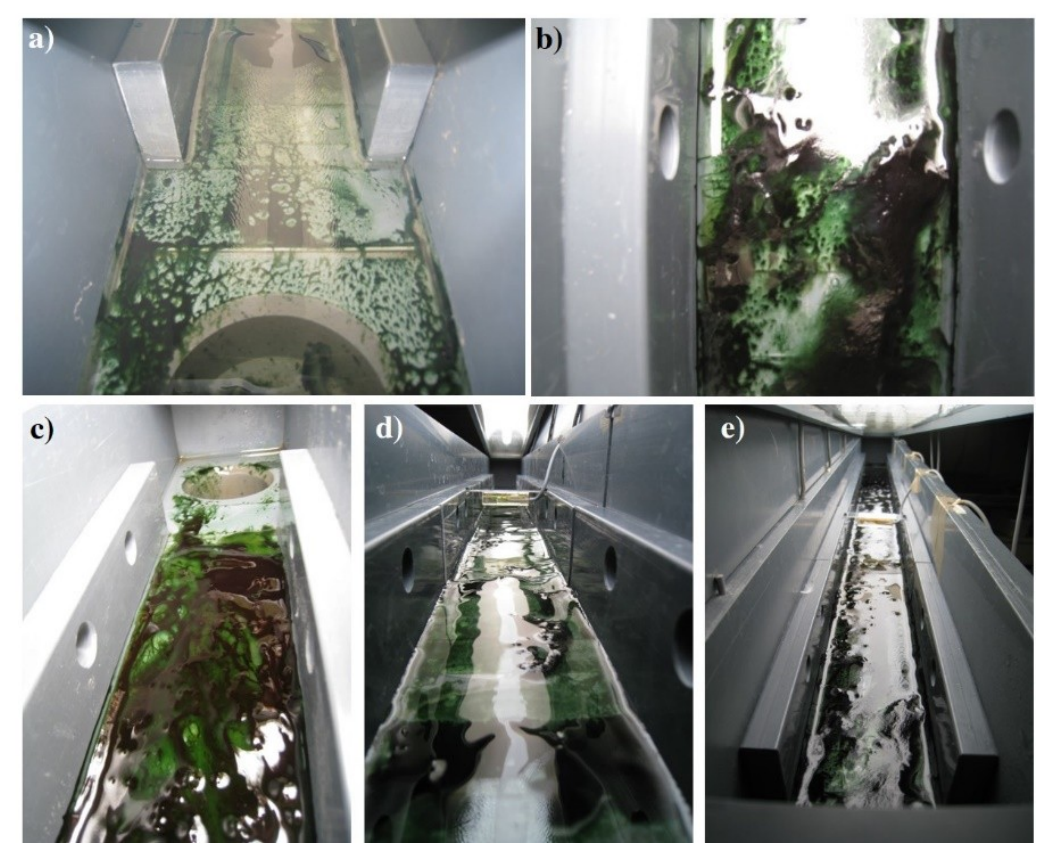

Figure 3. Details of LC1 biofilms growing in the incubator at the mature phase of development (a-c). Light sensor positioned under the lamp (d,e).

Biofilm detachment from the slides occurred in a number of cases, visible from the concomitant appearance of bare areas on the slides and biofilm flocs in the circulating medium, these representing the dispersion, i.e., the last phase of biofilms development. Beyond self-detachment, which occurs when losses, due for example to cell death, grazing, pathogens, etc., become equal to growth, other factors (e.g., flow disturbance, temperature, light and nutrient availability) may have an impact [20,56]. Nutrient concentration does not represent a limitation, as long as N:P ratio is maintained, when biofilms are grown on wastewater in both indoor and outdoor photobioreactors. Therefore, optimization of flow regime, temperature and light intensity are the main parameters to focus on for high quality biomass production when the process is scaled up to real plant operations. Additionally, biomass harvesting frequency has to be assessed in order to ensure an effective treatment of WWs. 


\subsection{Photosynthetic Characteristics}

Results of photosynthetic performance of light-acclimated cultures, obtained after PAM measurements, are reported in Figures 4-7 and in Tables S1-S8 are those obtained by statistical analysis to evaluate the effect of experimental conditions on photosynthetic parameters.

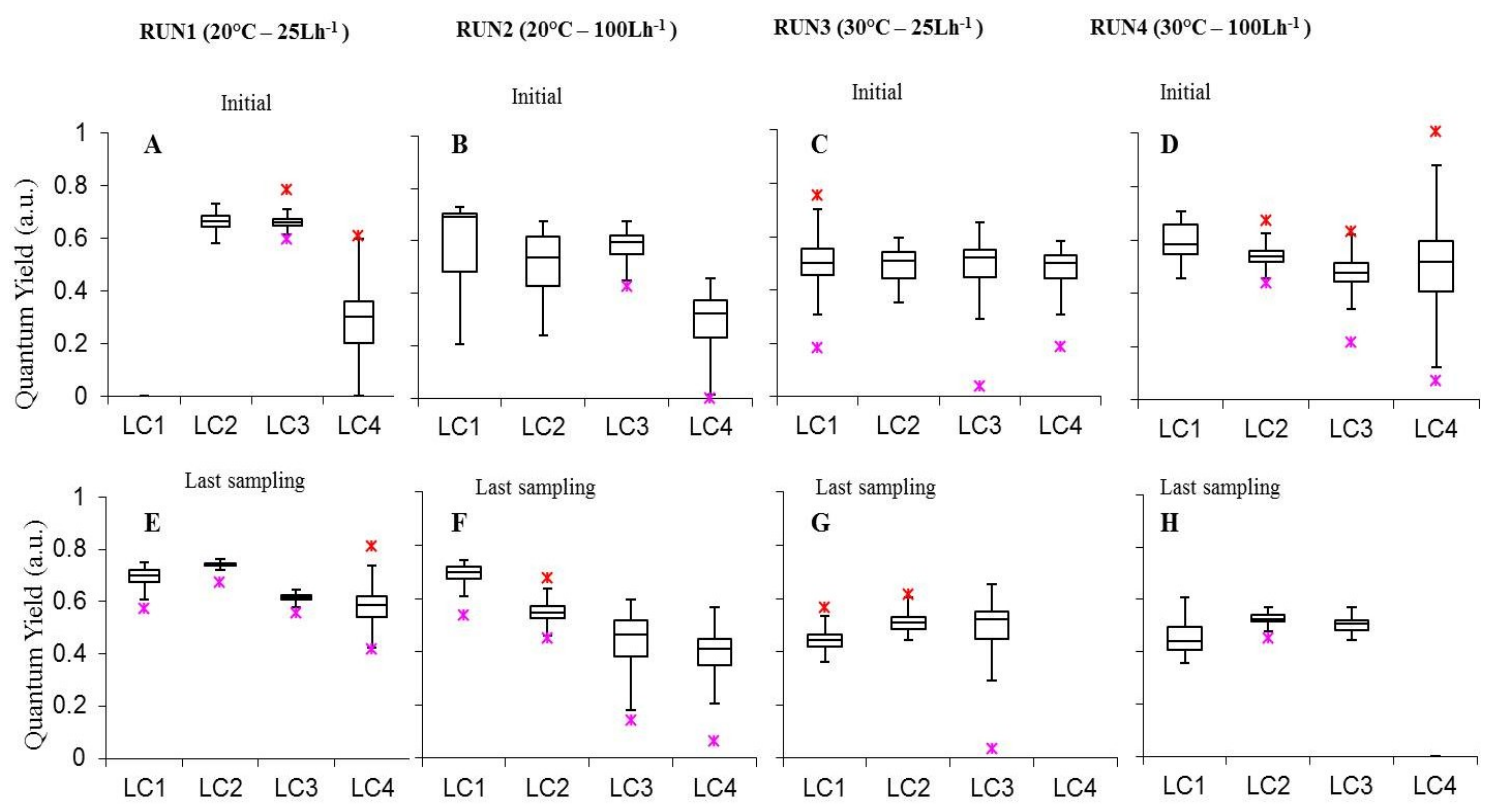

Figure 4. Box-plots relative to the comparison of quantum yield $\left(\Delta \mathrm{F} / \mathrm{F}_{\mathrm{m}}{ }^{\prime}\right)$ of photosystem II (PSII) measurements determined on all light-acclimated biofilms (Run1-Run4) at initial phase (A-D) and last sampling day $(\mathbf{E}-\mathbf{H})$. Run1-LC1in = not sampled.

The effective quantum yield of photosynthesis $\left(\Delta \mathrm{F} / \mathrm{F}_{\mathrm{m}}{ }^{\prime}\right)$ represents the efficiency of the whole-chain photosynthetic electron transport of steady-state photosynthesis in the light [57]. Values measured on the surface of intact biofilms, were included between $0.282 \pm 0.015$ (LC4in Run1) and $0.742 \pm 0.001$, with the latter occurring in 30-days biofilms at $60 \mu \mathrm{mol}$ photons $\mathrm{m}^{-2} \mathrm{~s}^{-1}, 20^{\circ} \mathrm{C}$ and $25 \mathrm{~L} \mathrm{~h}^{-1}$ (LC2ls Run1). Most yield values were included between 0.5 and 0.7 , falling in the ranges reported for natural biofilms from different environments, thus exposed at various ambient light intensities [31,58-60].

Analyzing separately the effect of experimental parameters on biofilm photosynthetic performance, we observed that, at initial stages, biofilm $\Delta \mathrm{F} / \mathrm{F}_{\mathrm{m}}{ }^{\prime}$ was not affected by variations in light conditions (Figure 4A-D Table S1). Conversely, in the last experimental day in Run $\Delta \mathrm{F} / \mathrm{F}_{\mathrm{m}}{ }^{\prime}$ increased from 15 to $60 \mu \mathrm{mol}$ photon $\mathrm{m}^{-2} \mathrm{~s}^{-1}$ (LC3ls-LC4ls $p=0$, LC21s-LC31s $p=0$ ) followed by a significant decrease from 60 to $120 \mu \mathrm{mol}$ photon $\mathrm{m}^{-2} \mathrm{~s}^{-1}(p=0.00001254)$. In Run2 a significant increase occurred from 15 to $120 \mu \mathrm{mol}$ photon $\mathrm{m}^{-2} \mathrm{~s}^{-1}$ (Run2 LC31s-LC4ls $p=0.0001251$, LC21s-LC3ls $p=0$, LC1ls-LC21s $p=0$ ) (Table S2).

Moreover, in all Runs but Run2, cultures at $60 \mu \mathrm{mol}$ photon $\mathrm{m}^{-2} \mathrm{~s}^{-1}$ showed significantly higher yield than biofilms grown at the highest irradiance $(p<0.05$ see Table S2) indicating a proper functioning of the phototrophic community at this irradiance and prospecting a suitable light condition for cultivating phototrophic biofilms in photobioreactors for WWT.

The effect of temperature was clearer in biofilms at the highest light intensities were significantly higher values were obtained at $20^{\circ} \mathrm{C}$ than $30^{\circ} \mathrm{C}$ at both flow velocities $(p<0.05$ see Table S2), likely because rates of enzymatic reactions involved in electron transport are temperature-dependent [61-64]. High temperature represents an excess energy and may lead to an imbalance between the energy supply and energy consumption by the redox reactions in the electron transport chain resulting in a progressive photoinactivation of PSII reaction centers [63]. 
As for the effect of flow rate on biofilm photosynthesis, initial stages yield showed a scattered distribution. The most relevant outcome was obtained at $60 \mu \mathrm{mol}$ photon $\mathrm{m}^{-2} \mathrm{~s}^{-1}$ where LC2 cultures attained significantly higher yields at $25 \mathrm{~L} \mathrm{~h}^{-1}$ than $100 \mathrm{~L} \mathrm{~h}^{-1}$ at $20^{\circ} \mathrm{C}$ (Run1 LC2in-Run2 LC2in $p=0$ ). This was also recorded at the runs' end at $20^{\circ} \mathrm{C}$ (Run1 LC2ls-Run2 LC2ls $p=0$ ) while no significant difference was found between yields at different flow rates at $30^{\circ} \mathrm{C}(p>0.05$ Table S2).

The combined effect of light, temperature, and flow was also evaluated on biofilms photosynthesis. In initial stage biofilms $\Delta \mathrm{F} / \mathrm{F}_{\mathrm{m}}{ }^{\prime}$ was significantly higher at $30 \mu \mathrm{mol}$ photon $\mathrm{m}^{-2} \mathrm{~s}^{-1}, 20^{\circ} \mathrm{C}, 25 \mathrm{~L} \mathrm{~h}^{-1}$ (Run1-LC3) than at all other conditions ( $p<0.05$ Table S1) suggesting that these irradiance, temperature, and flow values were the most favorable for light utilization in the photosynthetic process. Noteworthy, $\Delta \mathrm{F} / \mathrm{F}_{\mathrm{m}}{ }^{\prime}$ was higher at $60 \mu \mathrm{mol}$ photon $\mathrm{m}^{-2} \mathrm{~s}^{-1}, 20^{\circ} \mathrm{C}, 25 \mathrm{~L} \mathrm{~h}^{-1}$ (Run1-LC2) than at almost all the other conditions (Table S1). The only exception was the non-significant difference between Run1-LC2 and Run1-LC3 $(p=1)$. In the last phase, $60 \mu \mathrm{mol}$ photon $\mathrm{m}^{-2} \mathrm{~s}^{-1}, 20^{\circ} \mathrm{C}$ and $25 \mathrm{~L} \mathrm{~h}^{-1}$ (Run1 LC2) were the conditions providing higher yield values ( $p<0.05$ Table S2). This suggested that to maintain biofilm photosynthesis in optimal conditions, and all the processes related to it, which are essential for WWT, a full-scale photobioreactor might be operated at $20^{\circ} \mathrm{C}, 25 \mathrm{~L} \mathrm{~h}^{-1}$ and at an irradiance of 30 or $60 \mu \mathrm{mol}$ photon $\mathrm{m}^{-2} \mathrm{~s}^{-1}$, initially, and then at $60 \mu \mathrm{mol}$ photon $\mathrm{m}^{-2} \mathrm{~s}^{-1}$.

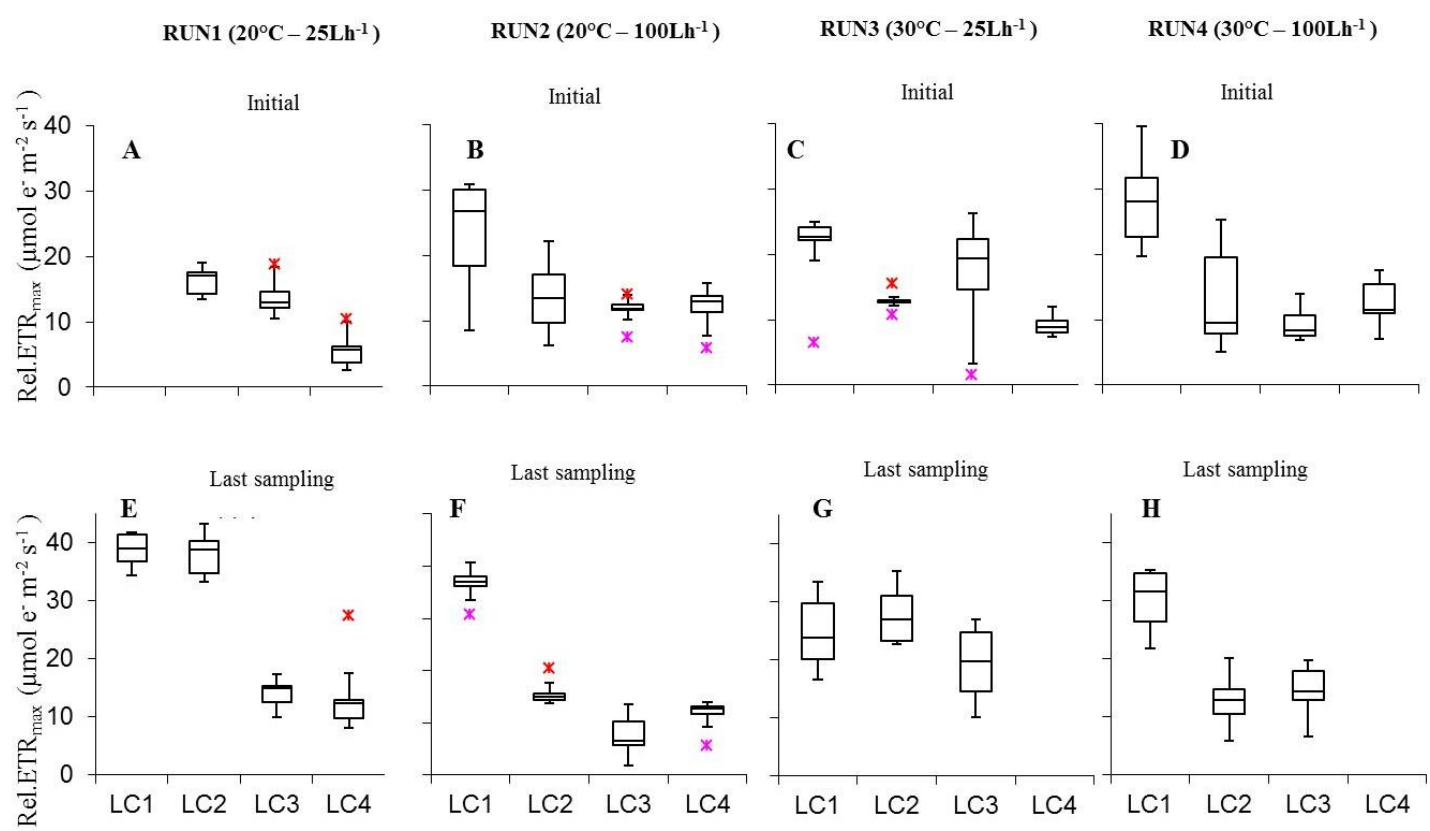

Figure 5. Box-plots relative to the comparison of rel.ETR $\mathrm{max}_{\operatorname{mal}}$ values determined on all light-acclimated biofilms (Run1-Run4) at initial phase (A-D) and last sampling day (E-H). Run1-LC1in = not sampled.

Photoacclimation of cultured biofilms to different experimental irradiances was indicated also by variations in ETR/I curve parameters such as rel.ETR $\max _{1}, \mathrm{I}_{\mathrm{k}}$, and $\alpha$ (Figures 5-7). Rel.ETR $\mathrm{max}_{\max }$ (Figure 5) varied between $5.5 \pm 0.9$ and $43.4 \pm 1.3 \mu \mathrm{mol} \mathrm{e}^{-} \mathrm{m}^{-2} \mathrm{~s}^{-1}$ (LC4in Run1 and LC1ac Run2, respectively).

Plotting rel.ETR $\max$ variations with irradiance did not show coherent effects both in initial and last day biofilms (Figure 5). In both cases, the most relevant result was the significant increase from 60 to $120 \mu \mathrm{mol}$ photon $\mathrm{m}^{-2} \mathrm{~s}^{-1}$ in Run2 $(p=0.0005674)$, reflecting the photoacclimation of the benthic phototrophic communities at increasing irradiance $[32,60,65]$. At higher temperature initial and last day biofilms did not show significant rel.ETR $\max _{\max }$ variations at both flow conditions (Tables S3 and S4); except for the higher rel.ETR $\max$ of LC1ls cultures at $25 \mathrm{~L} \mathrm{~h}^{-1}$ at $20^{\circ} \mathrm{C}(p=0.0004123)$. As for the effect of flow rate, only few variations were significant both in samples at the initial phase and at the last run day (Tables S3 and S4). The interaction of light, temperature and flow rate variation on rel.ETR $\max$ yielded different results between initial biofilms and cultures sampled at the last day. In the former

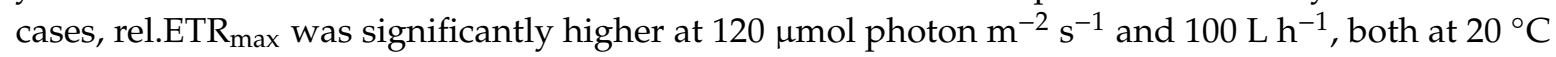


and $30{ }^{\circ} \mathrm{C}$, than at most of the parameters combinations tested (Table S3); while in the latter cases, rel.ETR $R_{\max }$, significantly increased at 60 and $120 \mu \mathrm{mol}$ photon $\mathrm{m}^{-2} \mathrm{~s}^{-1}$, at $20^{\circ} \mathrm{C}_{\text {and }} 25 \mathrm{~L} \mathrm{~h}^{-1}$ (Table S4).

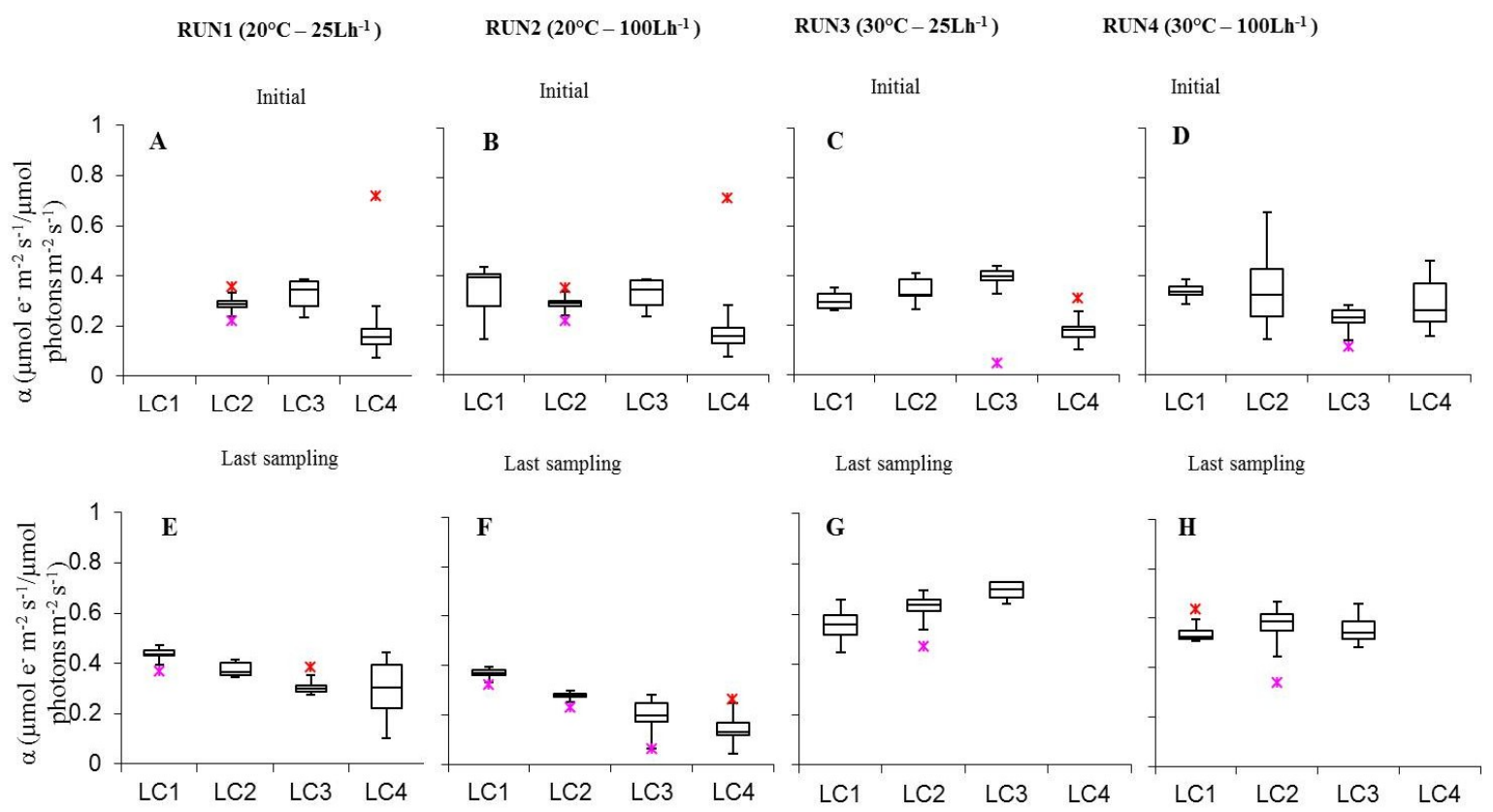

Figure 6. Box-plots relative to the comparison of $\alpha$ values determined on all light-acclimated biofilms (Run1-Run4) at initial phase (A-D) and last sampling day (E-H). Run1-LC1in = not sampled.

As for photosynthetic efficiency $(\alpha)$, it was included between $0.14 \pm 0.02$ (LC4 Run2) and $0.43 \pm 0.01$ (LC1ac Run1). The visual analysis of $\alpha$ values in relation to irradiance showed that in initial biofilms of Run1-3, $\alpha$ increased from 15 to $30 \mu \mathrm{mol}$ photon $\mathrm{m}^{-2} \mathrm{~s}^{-1}$ and decreased from 30 to $60 \mu \mathrm{mol}$ photon $\mathrm{m}^{-2} \mathrm{~s}^{-1}$ (Figure 6). Nevertheless, only the variation between LC 3 and LC4 at $20^{\circ} \mathrm{C}$ and $100 \mathrm{~L} \mathrm{~h}^{-1}$ was significant ( $p=0.004918$ ) (Table S5). In biofilms collected at runs' end, $\alpha$ increased at $20^{\circ} \mathrm{C}$, both at low and high flow rate, from 15 to $120 \mu \mathrm{mol}$ photon $\mathrm{m}^{-2} \mathrm{~s}^{-1}$. Some of the variations observed were significant, i.e., Run2LC1-Run2LC2 ( $p=0.01241)$, Run2LC2-Run2LC3 ( $p=0.03837)$ (Table S6). At the initial stage of development, temperature variations did not have a significant effect on $\alpha$ while at the last sampling day some significant variations occurred. In detail, at low flow, $\alpha$ was higher at $20^{\circ} \mathrm{C}$ than at $30^{\circ} \mathrm{C}(p<0.05$ see Table S6) in biofilms at both the highest light intensities while, at high flow, only at $120 \mu \mathrm{mol}$ photon $\mathrm{m}^{-2} \mathrm{~s}^{-1}(p=0.006375)$. Variation of $\alpha$ with temperature, likewise $\Delta \mathrm{F} / \mathrm{F}_{\mathrm{m}}{ }^{\prime}$, depends on the photochemical reactions that are temperature dependent (e.g enzymes of photophosporylation and electron transport and plastoquinone diffusion). As for the flow rate variation, similarly to temperature, no significant differences were observed in initial biofilms, at both temperatures. In cultures at the runs' end at $20^{\circ} \mathrm{C}$, significant higher $\alpha$ values were obtained at low than high flow at LC2 $(p=0.002964)$, LC3 ( $p=0.0001108)$, LC4 ( $p=1.894 \mathrm{E}-8)$. Regarding the interaction between light intensity, temperature, and flow rate, for biofilms in the initial phase it was not possible to find the conditions optimizing $\alpha$, while for cultures sampled at the runs' end two combinations were identified, 60 and $120 \mu$ mol photon $\mathrm{m}^{-2} \mathrm{~s}^{-1}, 20^{\circ} \mathrm{C}, 25 \mathrm{~L} \mathrm{~h}^{-1}$ (Table S6). 


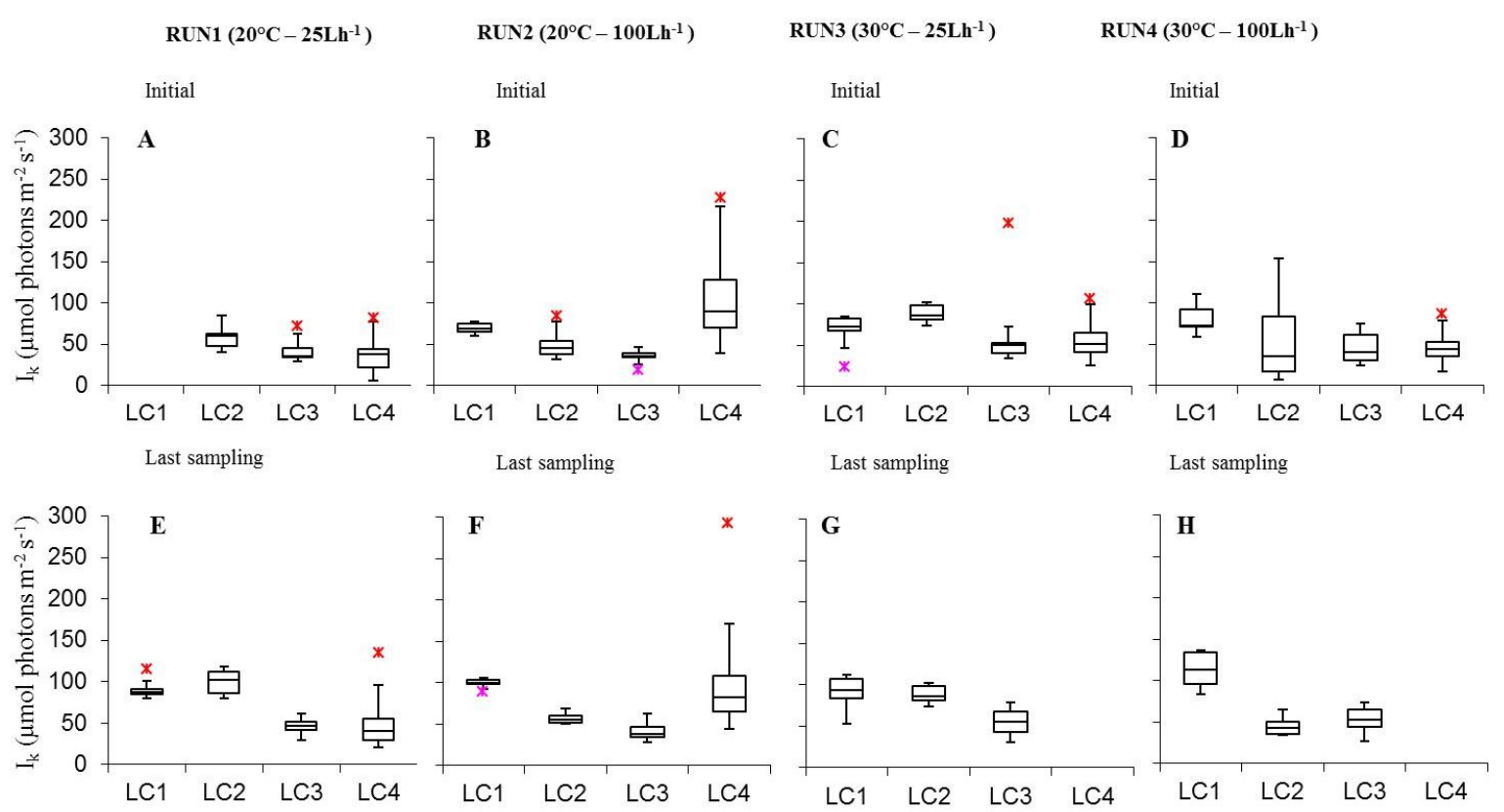

Figure 7. Box-plots relative to the comparison of $\mathrm{I}_{\mathrm{k}}$ values determined on all light-acclimated biofilms (Run1-Run4) at initial phase (A-D) and last sampling day (E-H). Run1-LC1in = not sampled.

$\mathrm{I}_{\mathrm{k}}$ ranged (Figure 7) between $34.8 \pm 3.2$ (LC3in Run2) and $128.1 \pm 5.2 \mu \mathrm{mol}$ photon $\mathrm{m}^{-2} \mathrm{~s}^{-1}$ (LC1ac Run2). Most values of rel.ETR $\mathrm{max}_{\max }$ and $\mathrm{I}_{\mathrm{k}}$ obtained matched those found for sub-tidal phototrophic biofilms from different geographical areas [32,60]. In biofilms at initial stage and at the last experimental day, light variations influenced $\mathrm{I}_{\mathrm{k}}$ only in few cases (Tables S7 and S8) while temperature had no effect on cultures at both phases of development, except for initial biofilms at $15 \mu \mathrm{mol}$ photon $\mathrm{m}^{-2} \mathrm{~s}^{-1}$ and $100 \mathrm{~L} \mathrm{~h}^{-1}$ with higher values at $20^{\circ} \mathrm{C}$ than at $30^{\circ} \mathrm{C}(p=0.005464)$. As for the flow rate, $\mathrm{I}_{\mathrm{k}}$ did not have a significant variation in initial cultures while being significantly higher at $20^{\circ} \mathrm{C}$ and lower at $30{ }^{\circ} \mathrm{C}$ at $100 \mathrm{~L} \mathrm{~h}^{-1}$ at almost all light conditions (Table S8). For the combined effect of light, temperature, and flow rate results were different between initial biofilms and cultures at the last sampling day. In the former cases, $\mathrm{I}_{\mathrm{k}}$ was significantly higher at the lowest light intensity, low temperature and high flow (Table S7); in the latter cases, $\mathrm{I}_{\mathrm{k}}$ was significantly higher at 60 and $120^{\circ} \mathrm{C} \mu \mathrm{mol}$ photon $\mathrm{m}^{-2} \mathrm{~s}^{-1}, 20^{\circ} \mathrm{C}$, $25 \mathrm{~L} \mathrm{~h}^{-1}$ (Table S8).

Photoinhibition, measured as the reduction of rel.ETR during ETR/I curve registration, occurred in almost all LC1, LC2, and LC3 samples at $470 \mu \mathrm{mol}$ photon $\mathrm{m}^{-2} \mathrm{~s}^{-1}$, irrespective of growth irradiance and biofilm developmental stage (Figures 8 and 9). 

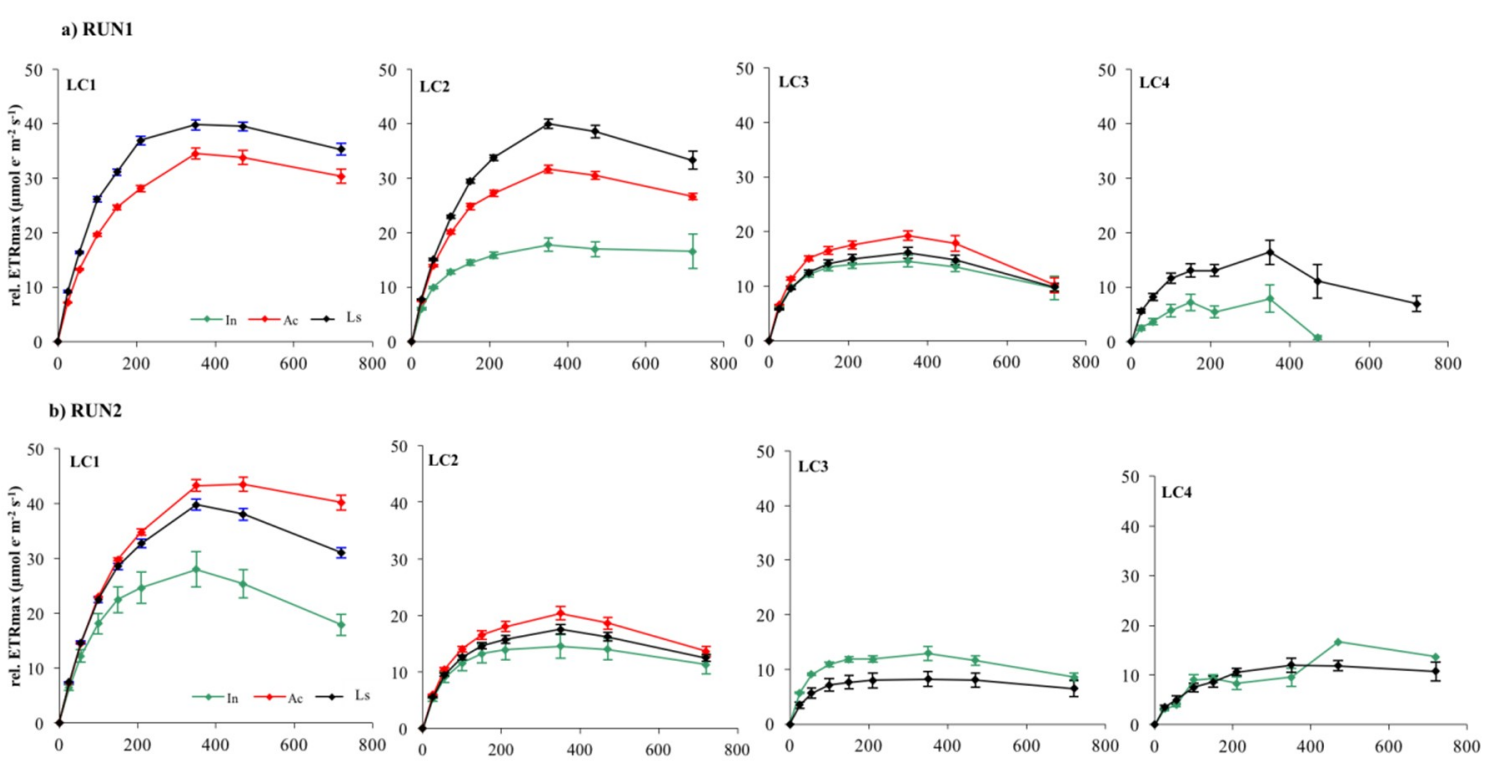

Figure 8. Electron Transport Rates versus Irradiance relative to LC1, LC2, LC3, and LC4 biofilms at different stage of development in Run1 (a) and Run2 (b). Each curve represents the mean of nine replicates.
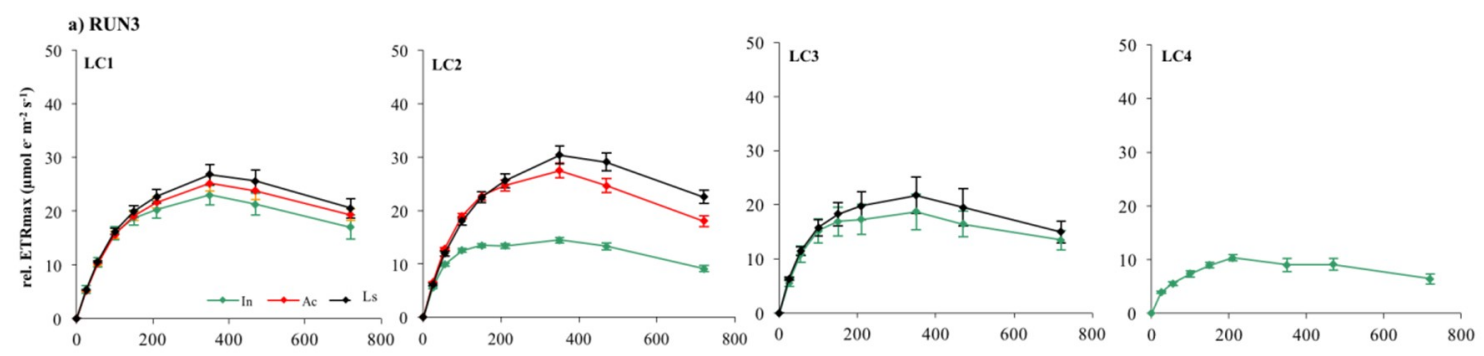

b) RUN4
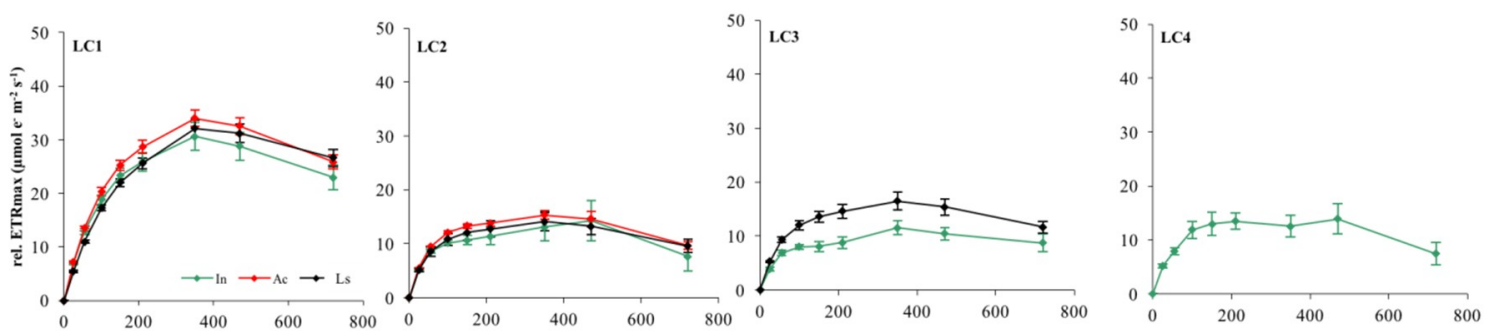

Figure 9. Electron transport rates versus irradiance relative to LC1, LC2, LC3, and LC4 biofilms at different stage of development in Run3 (a) and Run4 (b). Each curve represents the mean of nine replicates.

LC4 cultures showed photoinhibition at lower but, nevertheless, quite moderate irradiance (210-350 mmol photon $\mathrm{m}^{-2} \mathrm{~s}^{-1}$ ) considering that they were grown at the lowest light. This result suggests that the phototrophic community studied had the potential to acclimate to higher irradiances than those tested in the incubator cultures. Nevertheless, occurrence of photoinhibition in benthic communities during laboratory measurements and its relationship with the growth light regime is still quite controversial [33]. Photoinhibition may be often hidden by the self-shading effect within the biofilm matrix [28]. If the matrix is deep enough, decreases in the rate of oxygen production in the uppermost layer of biofilms with high irradiance are compensated for by increased photosynthesis of subsurface phototrophs, which receive only saturating or subsaturating irradiance $[28,32,66]$. On the contrary, fluorescence measurement of photosynthesis is derived mainly from the uppermost layers of 
phototrophs due to light attenuation with depth, particularly in thick mature biofilms $[33,35,67]$. Thus, the occurrence of photoinhibition reflects more the acclimation of surface cells to incident light rather than self-shading effects within the biofilm [33]. Therefore, ETR/I curves of LC1 and LC2 biofilms probably reflected the photoinhibition of phototrophs in the uppermost layers, particularly in the active and mature phases of development when communities were greatly stratified.

\subsection{Biomass Production}

Biomass accumulation has previously been shown to be linearly related to the decrease of subsurface light below the substratum $[40,48]$. The increase of biomass measurements over time indicated that natural mixed inocula were able to grow in culture after biofilm structure alteration caused by initial homogenizing treatment.

$\mathrm{Chl} a$ concentration, used to estimate the phototrophic biomass in the cultured biofilms, ranged between 0.16 and $125.10 \pm 1.52 \mathrm{mg} \mathrm{m}^{-2}$ (LC4in Run1 and LC21s Run1, respectively, Figure 10). Mean values were in the range reported for 7-days biofilms grown in situ on artificial substrata (up to 252.6 $\mathrm{mg} \mathrm{m}^{-2}$ ) [46] and for freshwater biofilms of rivers and streams impacted by nutrient-rich urban and agricultural waste discharges [68-70].
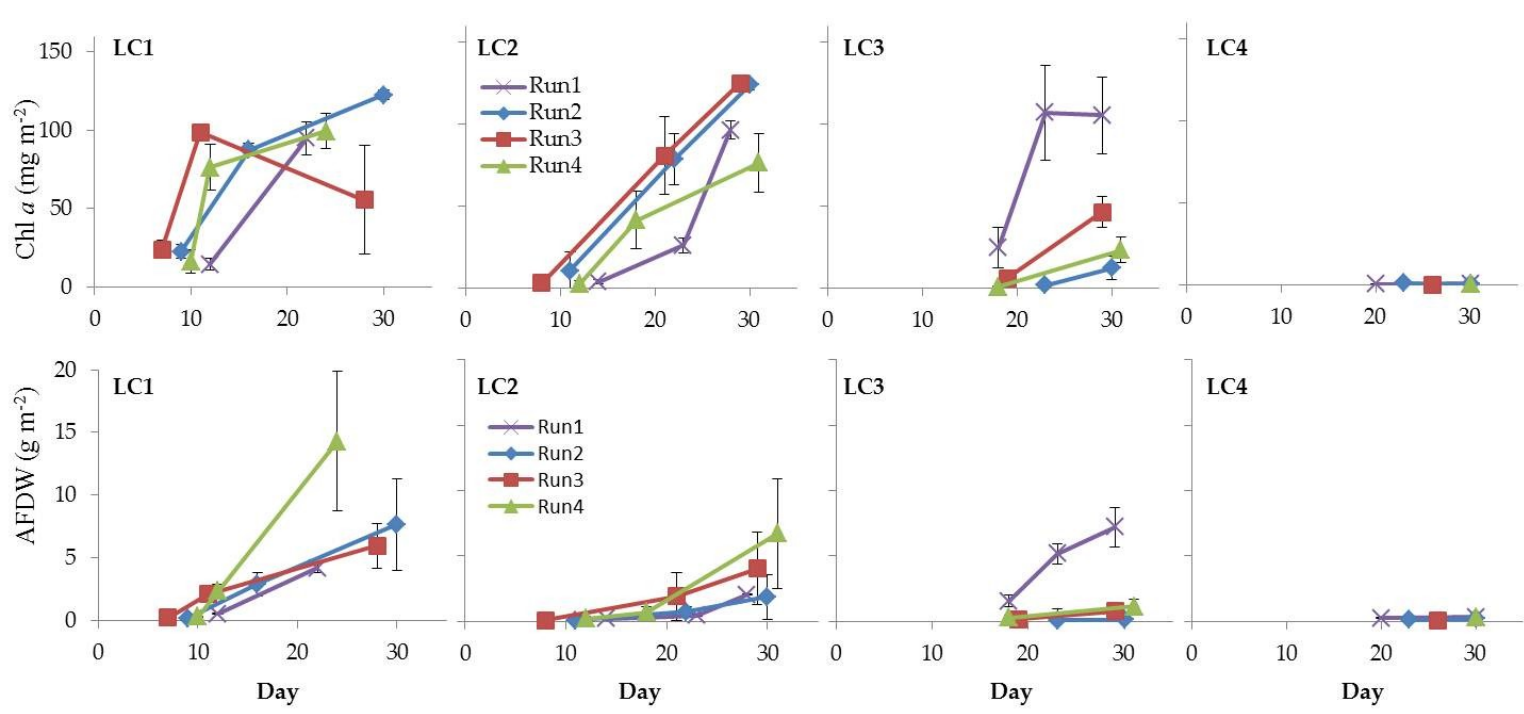

Figure 10. Temporal development of Chl $a$ and AFDW in LC1, LC2, LC3, and LC4 biofilms (Run1-Run4).

Looking at Chl $a$ trend, at 120 and $60 \mu \mathrm{mol}$ photons $\mathrm{m}^{-2} \mathrm{~s}^{-1}, \mathrm{Chl} a$ concentration increased over time following biofilm development, up to approximately $120 \mathrm{mg} \mathrm{m}^{-2}$ in final cultures. This suggested that $60 \mu \mathrm{mol}$ photons $\mathrm{m}^{-2} \mathrm{~s}^{-1}$ was sufficient for biofilm development and higher intensity did not appear to exert any additional effect. Nevertheless, at this irradiance a longer lag phase was required for biofilm growth than at $120 \mu \mathrm{mol}$ photons $\mathrm{m}^{-2} \mathrm{~s}^{-1}$. This might have implications in the selection of the light condition for culturing microbial-algal consortia in a wastewater photobioreactor.

Whole biofilm biomass, estimated as AFDW, grew up to $14.30 \pm 3.20 \mathrm{~g} \mathrm{~m}^{-2}$ (LC1ls Run4) (Figure 10). This value fell in the range reported for natural biofilms from streams both subjected or not to nutrient pollution [71,72]. Lower values, between ca. 23 and $37 \mathrm{mg} \mathrm{m}^{-2}$, were achieved in biofilms grown in artificial streams with wastewater at different sewage percentage [70]. A significant positive correlation was found between $\mathrm{Chl} a$ and AFDW (Table S9), suggesting that the phototrophic community represented the main component of the whole biofilm. This was confirmed by the autotrophic index (AI), which is a means of determining the metabolism/trophic nature of biofilms [53]. Most values were below 50 (Table 1), indicating that biofilms were autotrophs-dominated [73]. 
Table 1. Mean values \pm standard error of $\mathrm{AI}$ at initial (in), active (ac), 85\% light absorption, last sampling day of biofilm development in the four runs performed. ns = not sampled.

\begin{tabular}{|c|c|c|c|c|c|}
\hline Light Chamber & Sample & Run1 & Run2 & Run3 & Run4 \\
\hline \multirow{4}{*}{ LC1 } & in & ns & $9 \pm 5$ & $11 \pm 2$ & $24 \pm 7$ \\
\hline & ac & $38 \pm 5$ & $33 \pm 6$ & - & $31 \pm 4$ \\
\hline & $85 \%$ & $44 \pm 1$ & - & $21 \pm 2$ & - \\
\hline & ma & ns & $63 \pm 18$ & $144 \pm 57$ & $141 \pm 23$ \\
\hline \multirow{3}{*}{ LC2 } & in & $62 \pm 11$ & 5 & $45 \pm 22$ & $131 \pm 73$ \\
\hline & ac & $19 \pm 2$ & $9 \pm 3$ & $23 \pm 11$ & $23 \pm 12$ \\
\hline & ld & $21 \pm 1$ & $15 \pm 8$ & $33 \pm 13$ & $87 \pm 30$ \\
\hline \multirow{3}{*}{ LC3 } & in & $94 \pm 52$ & $55 \pm 10$ & $35 \pm 15$ & $331 \pm 114$ \\
\hline & ac & $57 \pm 20$ & - & - & - \\
\hline & ld & $68 \pm 1$ & $15 \pm 7$ & $18 \pm 5$ & $48 \pm 7$ \\
\hline \multirow{2}{*}{ LC4 } & in & $860 \pm 165$ & $454 \pm 367$ & 363 & 742 \\
\hline & ld & $655 \pm 284$ & $748 \pm 382$ & - & - \\
\hline
\end{tabular}

Values of ca. 140 were obtained in LC1 mature cultures at the highest light in Run3 and Run4, indicating a balance between the photo- and heterotrophic components [71,74]. Nevertheless, in LC1 cultures in Run3 and Run4 the heterotrophic component became, in terms of biomass, more important as biofilms grew. The AI values, in fact, increased over time due to the increase of AFDW and the saturation of $\mathrm{Chl} a$ in mature communities. The raise of heterotrophs might be explained by the increased amount, in mature biofilms at high light intensity, of algal exudates that represent a high-quality organic substrate for bacteria [71,75,76]. Wagner et al. [77] observed a shift towards bacterial consumption of DOC of autochthonous origin in phototrophic stream biofilms at high light intensity. As explained, cultured mature biofilms were dominated by filamentous cyanobacteria able to produce high amounts of exopolysaccharides [38,40]. Finally, heterotrophs strongly dominated cultures at the lowest irradiances [37] where values were above 200 in all samples.

Biomass productivity was included between 0.01 (LC3in Run2, LC4in in Run2 and Run3) and $2.10 \pm 0.36$ (LC1ma Run4) g DW m ${ }^{-2} \mathrm{~d}^{-1}$ (Table 2).

Table 2. Mean values \pm standard error of biomass productivity ( $\mathrm{DW} \mathrm{g} \mathrm{m}^{-2} \mathrm{~d}^{-1}$ ) at initial (in) and active (ac) biofilms and cultures at last sampling day (ls) in the four runs performed. ns = not sampled.

\begin{tabular}{cccccc}
\hline Light Chamber & Sample & Run & Run & Run3 & Run \\
\hline \multirow{2}{*}{ LC1 } & in & ns & $0.14 \pm 0.04$ & $0.26 \pm 0.04$ & $0.20 \pm 0.02$ \\
& ac & $0.25 \pm 001$ & $0.80 \pm 0.08$ & $1.09 \pm 0.15$ & $0.91 \pm 0.04$ \\
& ls & $0.81 \pm 0.08$ & $1.08 \pm 0.09$ & $1.36 \pm 0.40$ & $2.10 \pm 0.36$ \\
LC2 & in & $0.04 \pm 0.00$ & $0.32 \pm 0.18$ & $0.04 \pm 0.00$ & $0.06 \pm 0.02$ \\
& ac & $0.13 \pm 0.01$ & $0.20 \pm 0.04$ & $0.37 \pm 0.10$ & $0.24 \pm 0.06$ \\
& ls & $0.37 \pm 0.01$ & $0.33 \pm 0.12$ & $0.51 \pm 0.09$ & $0.70 \pm 0.21$ \\
LC3 & in & $0.14 \pm 0.02$ & $0.01 \pm 0.00$ & $0.03 \pm 0.01$ & $0.04 \pm 0.01$ \\
& ac & $0.29 \pm 0.11$ & - & - & - \\
LC4 & ls & $0.51 \pm 0.05$ & $0.09 \pm 0.06$ & $0.08 \pm 0.01$ & $0.21 \pm 0.05$ \\
& in & $0.03 \pm 0.00$ & $0.01 \pm 0.01$ & $0.01 \pm 0.00$ & $0.03 \pm 0.01$ \\
\hline
\end{tabular}

Productivity was consistent with those reported [78] for mixed biofilms composed of green algae and diatoms in a lab-scale biofilm reactor $\left(0.97-2.08 \mathrm{~g} \mathrm{DW} \mathrm{m}^{-2} \mathrm{~d}^{-1}\right)$. The highest productivity values obtained here were higher than those attained with three different biofilm-forming cyanobacterial isolates grown in the same system [15] and with the green alga Chlorella vulgaris grown in a rotating algal bioreactor [17]. Higher values were reported for an algal biofilm grown in a photobioreactor [26]. 


\section{Conclusions}

This study provided new insights into photosynthetic activity of light-acclimated cultures, contributing to the knowledge of wastewater biofilm ecophysiology, in light of their exploitation in water bioremediation. The difficulty of studying these communities in nature, due to the complex interactions among several environmental factors, was overridden in the flow lane system, which allowed the investigation of key variables that influence photosynthetic performance.

- The tested light-dark cycle appeared to be suitable for community development and functioning.

- It was possible to identify light intensity, temperature, and flow value favoring photosynthetic activity, i.e., $60 \mu \mathrm{mol}$ photons $\mathrm{m}^{-2} \mathrm{~s}^{-1}, 20^{\circ} \mathrm{C}, 25 \mathrm{I}^{-1}$. This has implications for biomass accumulation and nutrient uptake related to photosynthesis. Therefore, this set of values appears to be appropriate for the optimal operating of a WWT photobioreactor that purifies municipal sewage by means of mixed phototrophic biofilms.

- Further development would be in the cultivation of these microbial communities in wastewater effluents to evaluate the treatment efficiency at the set of conditions here identified.

Supplementary Materials: The following are available online at http://www.mdpi.com/2076-2607/7/8/252/s1, Table S1: Results of ANOVA and Tukey's HSD testing with factors irradiance, temperature and flow on $\Delta \mathrm{F} / \mathrm{Fm}^{\prime}$ in initial biofilms. Tukey's $Q$ below the diagonal, $p$ value above the diagonal. Significant comparisons are red. Table S2: Results of ANOVA and Tukey's HSD testing with factors irradiance, temperature and flow on $\Delta F / F^{\prime}$ in biofilms at the last sampling day. Tukey's $Q$ below the diagonal, $p$ value above the diagonal. Significant comparisons are red. Table S3: Results of ANOVA and Tukey's HSD testing with factors irradiance, temperature and flow on rel.ETRmax in initial biofilms. Tukey's $Q$ below the diagonal, $p$ value above the diagonal. Significant comparisons are red. Table S4: Results of ANOVA and Mann-Whitney test testing with factors irradiance, temperature and flow on rel.ETRmax in biofilms at the last sampling day. Significant comparisons are red. Table S5: Results of ANOVA and Tukey's HSD testing with factors irradiance, temperature and flow on $\alpha$ in initial biofilms. Tukey's Q below the diagonal, $p$ value above the diagonal. Significant comparisons are red. Table S6: Results of ANOVA and Tukey's HSD testing with factors irradiance, temperature and flow on $\alpha$ in biofilms at the last sampling day. Tukey's $Q$ below the diagonal, $p$ value above the diagonal. Significant comparisons are red. Table S7: Results of ANOVA and Tukey's HSD testing with factors irradiance, temperature and flow on Ik in initial biofilms. Tukey's Q below the diagonal, $p$ value above the diagonal. Significant comparisons are red. Table S8: Results of ANOVA and Tukey's HSD testing with factors irradiance, temperature and flow on Ik in biofilms at the last sampling day. Tukey's Q below the diagonal, $p$ value above the diagonal. Significant comparisons are red. Table S9: Results of Spearman's rho-statistic applied to test the correlation between Chl a and AFDW.

Author Contributions: A.G. and F.D.P. collected samples, performed the experimental runs, analyzed the data. A.G., F.D.P. and R.C. wrote and edited the manuscript.

Funding: This work was partially conducted within the framework of EU project PHOBIA (QLK3-CT2002-01938).

Conflicts of Interest: The authors declare no conflict of interest.

\section{References}

1. Stott, R. Handbook of Water and Wastewater Microbiology; Mara, D., Horen, N., Eds.; Academic Press: London, UK, 2003; p. 832.

2. Gonçalves, A.L.; Pires, J.C.M.; Simões, M. A review on the use of microalgal consortia for wastewater treatment. Algal Res. 2017, 24, 403-415. [CrossRef]

3. Liu, J.; Wua, Y.; Wub, C.; Muylaert, K.; Vyverman, W.; Han-Yu, H.-Q.; Muñoz, R.; Rittmann, B. Advanced nutrient removal from surface water by a consortium of attached microalgae and bacteria: A review. Bioresour. Technol. 2017, 241, 1127-1137. [CrossRef]

4. Muñoz, R.; Guieysse, B. Algal-bacterial processes for the treatment of hazardous contaminants: A review. Water Res. 2006, 40, 2799-2815. [CrossRef]

5. Posadas, E.; del Mar Morales, M.; Gomez, C.; Acien, G.; Muñoz, R. Influence of pH and $\mathrm{CO}_{2}$ source on the performance of microalgae-based secondary domestic wastewater treatment in outdoors pilot raceways. Chem. Eng. J. 2015, 265, 239-248. [CrossRef]

6. Oswald, W.J. Ponds in the twenty-first century. Water Sci. Technol. 1995, 21, 1-8. [CrossRef] 
7. Park, J.B.K.; Craggs, R.J.; Tanner, C.C. Eco-friendly and low-cost enhanced pond and wetland (EPW) system for the treatment of secondary wastewater effluent. Ecol. Eng. 2018, 120, 170-179. [CrossRef]

8. Craggs, R.J.; Adey, W.H.; Jenson, K.R.; St. John, M.S.; Green, F.B.; Oswald, W.J. Phosphorus removal from wastewater using an algal turf scrubber. Water Sci. Technol. 1996, 33, 191-198 doiorg/101016/0273. [CrossRef]

9. De Souza Celente, G.; Colares, G.S.; Machado, Ê.L.; Lobo, E.A. Algae turf scrubber and vertical constructed wetlands combined system for decentralized secondary wastewater treatment. Environ. Sci. Pollut. Res. 2019, 26, 9931-9937. [CrossRef]

10. Church, J.; Ryu, H.; Sadmani, A.H.M.A.; Randall, A.A.; Domingo, J.S.; Lee, W.H. Multiscale investigation of a symbiotic microalgal-integrated fixed film activated sludge (MAIFAS) process for nutrient removal and photo-oxygenation. Bioresour. Technol. 2018, 268, 128-138. [CrossRef]

11. Luo, S.; Berge, J.A.; He, Z.; Young, E.B. Algal-microbial community collaboration for energy recovery and nutrient remediation from wastewater in integrated photobioelectrochemical systems. Algal Res. 2017, 24 , 527-539.

12. Wang, M.; Keeley, R.; Zalivina, N.; Halfhide, T.; Scott, K.; Zhang, Q.; van der Steen, P.; Ergas, S.J. Advances in algal-prokaryotic wastewater treatment: A review of nitrogen transformations, reactor configurations and molecular tools. J. Environ. Manag. 2018, 217, 845-857. [CrossRef]

13. Rawat, I.; Ranjith Kumar, R.; Mutanda, T.; Bux, F. Dual role of microalgae: Phycoremediation of domestic wastewater and biomass production for sustainable biofuels production. Appl. Energy 2011, 88, 3411-3424. [CrossRef]

14. Ferreira, A.; Marques, P.; Ribeiro, B.; Assemany, P.; de Mendonça, H.V.; Barata, A.; Oliveira, A.C.; Reis, A.; Pinheiro, H.M.; Gouveia, L. Combining biotechnology with circular bioeconomy: From poultry, swine, cattle, brewery, dairy and urban wastewaters to biohydrogen. Environ. Res. 2018, 164, 32-38. [CrossRef]

15. Gismondi, A.; Di Pippo, F.; Bruno, L.; Antonaroli, S.; Congestri, R. Phosphorus removal coupled to bioenergy production by three cyanobacterial isolates in a biofilm dynamic growth system. Int. J. Phytoremediat. 2016, 18, 869-876. [CrossRef]

16. Schoenung, S.M.; Efroymson, R.A. Algae Production from Wastewater Resources: An Engineering and Cost Analysis; Oak Ridge National Laboratory: Oak Ridge, TN, USA, 2018; pp. 1-13. Available online: https: //info.ornl.gov/sites/publications/Files/Pub105632.pdf (accessed on 10 June 2019).

17. Gross, M.; Henry, W.; Michael, C.; Wen, Z. Development of a rotating algal biofilm growth system for attached microalgae growth with in situ biomass harvest. Bioresour. Technol. 2013, 150, 195-201. [CrossRef]

18. Kesaano, M.; Sims, R.C. Algal biofilm based technology for wastewater treatment. Algal Res. 2014, 5, $231-240$. [CrossRef]

19. Udaiyappan, A.F.M.; Hasan, H.A.; Takriff, M.S.; Abdullah, S.R.S. A review of the potentials, challenges and current status of microalgae biomass applications in industrial wastewater treatment. J. Water Process Eng. 2017, 20, 8-21. [CrossRef]

20. Mantzorou, A.; Ververidis, F. Microalgal biofilms: A further step over current microalgal cultivation techniques. Sci. Total Environ. 2019, 651, 3187-3201. [CrossRef]

21. Hoh, D.; Watson, S.; Kan, E. Algal biofilm reactors for integrated wastewater treatment and biofuel production: A review. Chem. Eng. J. 2016, 287, 466-473. [CrossRef]

22. Sabater, S.; Guasch, H.; Romaní, A.; Muñoz, I. The effect of biological factors on the efficiency of river biofilms in improving water quality. Hydrobiologia 2002, 469, 149-156. [CrossRef]

23. Boelee, N.C.; Temmink, H.; Janssen, M.; Buisman, C.J.N.; Wijffels, R.H. Nitrogen and phosphorus removal from municipal wastewater effluent using microalgal biofilms. Water Res. 2011, 45, 5925-5933. [CrossRef]

24. Sukačová, K.; Trtílek, M.; Rataj, T. Phosphorus removal using a microalgal biofilm in a new biofilm photobioreactor for tertiary wastewater treatment. Water Res. 2015, 71, 55-63. [CrossRef]

25. Zhang, Q.; Li, X.; Guo, D.; Ye, T.; Xiong, M.; Zhu, L.; Liu, C.; Jin, S.; Hu, Z. Operation of a vertical algal biofilm enhanced raceway pond for nutrient removal and microalgae-based byproducts production under different wastewater loadings. Bioresour. Technol. 2018, 253, 323-332. [CrossRef]

26. Orfanos, A.G.; Manariotis, I.D. Algal biofilm ponds for polishing secondary effluent and resource recovery. J. Appl. Phycol. 2019, 31, 1765-1772. [CrossRef]

27. Guzzon, A.; Bohn, A.; Diociaiuti, M.; Albertano, P. Cultured phototrophic biofilms for phosphorus removal in wastewater treatment. Water Res. 2008, 42, 4357-4367. [CrossRef] 
28. Hill, W.R. Effects of Light. In Algal Ecology-Freshwater Benthic Ecosystems; Stevenson, R.J., Bothwell, M.L., Lowe, R.L., Eds.; Academic Press: San Diego, CA, USA, 1996; pp. 121-148.

29. Stevenson, R.J. An introduction to algal ecology in freshwater benthic habitats. In Algal Ecology-Freshwater Benthic Ecosystems; Stevenson, R.J., Bothwell, M.L., Lowe, R.L., Eds.; Academic Press: San Diego, CA, USA, 1996; pp. 3-30.

30. Hartig, P.; Wolfstein, K.; Lippemeir, S.; Colijn, F. Photosynthetic activity of natural microphytobenthos populations measured by fluorescence (PAM) and 14C-tracer methods: A comparison. Mar. Ecol. Prog. Ser. 1998, 166, 53-62. [CrossRef]

31. Kühl, M.; Glud, R.N.; Borum, J.; Roberts, R.; Rysgaard, S. Photosynthetic performance of surface-associated algae below sea ice as measured with a pulse-amplitude-modulated (PAM) fluorometer and $\mathrm{O}_{2}$ microsensors. Mar. Ecol. Prog. Ser. 2001, 223,1-14. [CrossRef]

32. Underwood, G.J.C. Adaptations of tropical marine microphytobenthic assemblages along a gradient of light and nutrient availability in Suva Lagoon, Fiji. Eur. J. Phycol. 2002, 37, 449-462. [CrossRef]

33. Roberts, S.; Sabater, S.; Beardall, J. Benthic microalgal colonization in streams of different riparian cover and light availability. J. Phycol. 2004, 40, 1004-1012. [CrossRef]

34. Consalvey, M.; Perkins, R.G.; Paterson, D.M.; Underwood, G.J.C. PAM fluorescence: A beginners guide for benthic diatomists. Diatom Res. 2005, 20, 1-22. [CrossRef]

35. Morelle, J.; Orvain, F.; Claquin, P. A simple, user friendly tool to readjust raw PAM data from field measurements to avoid over-or underestimating of microphytobenthos photosynthetic parameters. J. Exp. Mar. Biol. Ecol. 2018, 503, 13-146. [CrossRef]

36. Campbell, D.; Hurry, V.; Clarke, A.K.; Gustafsson, P.; Öquist, G. Chlorophyll fluorescence analysis of cyanobacterial photosynthesis and acclimation. Microbiol. Mol. Biol. Rev. 1998, 62, 667-683.

37. Roeselers, G.; Zippel, B.; Staal, M.; Van Loosdrecht, M.; Muyzer, G. On the reproducibility of microcosm experiments-different community composition in parallel phototrophic biofilm microcosms. FEMS Microbiol. Ecol. 2006, 58, 169-178. [CrossRef]

38. Di Pippo, F.; Bohn, A.; Congestri, R.; De Philippis, R.; Albertano, P. Capsular polysaccharides of cultured phototrophic biofilms. Biofouling 2009, 25, 495-504. [CrossRef]

39. Di Pippo, F.; Bohn, A.; Cavalieri, F.; Albertano, P. ${ }^{1} \mathrm{H}-\mathrm{NMR}$ analysis of water mobility in cultured phototrophic biofilms. Biofouling 2011, 27, 327-336. [CrossRef]

40. Di Pippo, F.; Ellwood, N.T.W.; Guzzon, A.; Bohn, A.; Congestri, R. Diversity and biomass accumulation in cultured phototrophic biofilms. Eur. J. Phycol. 2014, 49, 384-394. [CrossRef]

41. Albertano, P.; Congestri, R.; Shubert, L.E. Cyanobacterial biofilms in sewage treatment plants along the Tyrrhenian coast (Mediterranean Sea), Italy. Algol. Stud. 1999, 94, 13-24. [CrossRef]

42. Congestri, R.; Sangiorgi, V.C.; Albertano, P. Cytomorphology and distribution of periphytic cyanobacteria in one Italian waste water treatment plant. Algol. Stud. 2003, 109, 185-195. [CrossRef]

43. Guzzon, A.; Congestri, R.; Albertano, P. Light-induced changes in photosynthesis and structure of cyanobacteria cultured biofilms from an Italian wastewater treatment plant. Algol. Stud. 2005, 117, 223-228. [CrossRef]

44. Congestri, R.; Cox, E.J.; Cavacini, P.; Albertano, P. Diatoms (Bacillariophyta) in phototrophic biofilms colonising an Italian wastewater treatment plant. Diatom Res. 2005, 20, 241-255. [CrossRef]

45. Congestri, R.; Di Pippo, F.; De Philippis, R.; Paradossi, G.; Albertano, P. Seasonal succession of phototrophic biofilms in an Italian wastewater treatment plant: Biovolume, spatial structure and exopolysaccharides. Aquat. Microb. Ecol. 2006, 45, 301-312. [CrossRef]

46. Guzzon, A.; Albertano, P. Annual photosynthetic response of phototrophic biofilms from an Italian wastewater treatment plant. Algol. Stud. 2009, 131, 87-102. [CrossRef]

47. Stanier, R.Y.; Kunisawa, R.; Mandel, M.; Cohen-Bazire, G. Purification and properties of unicellular blue-green algae (Order Chroococcales). Bacteriol. Rev. 1971, 35, 171-205.

48. Zippel, B.; Rijstenbil, J.; Neu, T.R. A flow-lane incubator for studying freshwater and marine phototrophic biofilms. J. Microbiol. Met. 2007, 70, 336-345. [CrossRef]

49. Genty, B.; Briantais, J.M.; Baker, N.R. The relationship between the quantum yield of photosynthetic electron and quenching of chlorophyll fluorescence. Biochim. Biophys. Acta 1989, 990, 87-92. [CrossRef] 
50. Schreiber, U.; Hormann, H.; Neubauer, C.; Klughammer, C. Assessment of photosystem II photochemical quantum yield by chlorophyll fluorescence quenching analysis. Aust. J. Plant Physiol. 1995, 22, $209-220$. [CrossRef]

51. Webb, W.L.; Newton, M.; Starr, D. Carbon dioxide exchange of Alnus rubra. Oecologia 1974, 17, $281-291$. [CrossRef]

52. Jeffrey, S.W.; Humphrey, G.F. New spectrophotometric equations for determining chlorophylls $a, b, c_{1}$ and $c_{2}$ in higher plants, algae and natural phytoplankton. Biochem. Physiol. Pflanz. 1975, 167, 191-194. [CrossRef]

53. APHA. Standard Methods for the Examination of Water and Wastewater, 20th ed.; Clesceri, L.S., Geenberg, A.E., Eaton, A.D., Eds.; APHA, AWWA, WEF: Washington, DC, USA, 1998.

54. Sokal, R.R.; Rohlf, F.J. Biometry: The Principles and Practice of Statistics in Biological Research, 3rd ed.; WH Freeman and Co.: New York, NY, USA, 1995; pp. 1-887.

55. Di Pippo, F.; Congestri, R. Culturing Toxic Benthic Blooms: The Fate of Natural Biofilms in a Microcosm System. Microorganisms 2017, 5, 46. [CrossRef]

56. Boulêtreau, S.; Garabétian, F.; Sauvage, S.; Sánchez-Pérez, J.-M. Assessing the importance of a self-generated detachment process in river biofilm models. Freshw. Biol. 2006, 51, 901-912. [CrossRef]

57. Kromkamp, J.C.; Forster, R.M. The use of variable fluorescence measurements in aquatic ecosystems: Differences between multiple and single turnover measuring protocols and suggested terminology. Eur. J. Phycol. 2003, 38, 103-112. [CrossRef]

58. Barranguet, C.; Van den Ende, F.P.; Rutgers, M.; Breure, A.M.; Greijdanus, M.; Sinke, J.J.; Admiraal, W. Copper-induced modifications of the trophic relations in riverine algal-bacterial biofilms. Environ. Toxicol. Chem. 2003, 22, 1340-1349.

59. Rascher, U.; Lakatos, M.; Büdel, B.; Lüttge, U. Photosynthethic field capacity of cyanobacteria of a tropical inselberg of the GuaianaHoghlands. Eur. J. Phycol. 2003, 38, 247-256. [CrossRef]

60. Lugomela, C.; Söderbäck, E.; Björk, M. Photosynthesis-rates in cyanobacteia-dominated sub-tidal biofilms near Zanzibar, Tanzania. Estuar. Coast. Shelf Sci. 2005, 63, 439-446. [CrossRef]

61. Davison, I.R. Environmental effects on algal photosynthesis: Temperature. J. Phycol. 1991, 27, 2-8. [CrossRef]

62. De Nicola, D.M. Periphyton responses to temperature at different ecological levels. In Algal Ecology-Freshwater Benthic Ecosystems; Stevenson, R.J., Bothwell, M.L., Lowe, R.L., Eds.; Academic Press: San Diego, CA, USA, 1996; pp. 150-183.

63. Huner, N.P.A.; Maxwell, D.P.; Gray, G.R.; Savitch, L.V.; Krol, M.; Ivanov, A.G.; Falk, S. Sensing environmental temperature change through imbalances between energy supply and energy consumption: Redox state of photosystem II. Physiol. Plant 1996, 98, 358-364. [CrossRef]

64. Lazár, D. Chlorophyll a fluorescence induction. Biochim. Biophys. Acta 1999, 1412, 1-28.

65. McMinn, A.; Runcie, J.W.; Riddle, M. Effect of seasonal sea ice breakout on the photosynthesis of benthic diatom mats at Casey, Antarctica. J. Phycol. 2004, 40, 62-69. [CrossRef]

66. Dodds, W.K.; Biggs, B.J.F.; Lowe, R.L. Photosynthesis-irradiance patterns in benthic microalgae: Variations as a function of assemblage thickness and community structure. J. Phycol. 1999, 35, 42-53. [CrossRef]

67. Barranguet, C.; van Beusekom, S.A.M.; Veuger, B.; Neu, T.R.; Manders, E.M.M.; Sinke, J.J.; Admiraal, W. Studying undisturbed autotrophic biofilms: Still a technical challenge. Aquat. Microb. Ecol. 2004, 34, 1-9. [CrossRef]

68. Taylor, S.L.; Roberts, S.C.; Walsh, C.J.; Hatt, B.E. Catchment urbanisation and increased benthic algal biomass in streams: Linking mechanisms to management. Freshw. Biol. 2004, 49, 835-851. [CrossRef]

69. Carr, G.M.; Morin, A.; Chambers, P.A. Bacteria and algae in stream periphyton along a nutrient gradient. Freshw. Biol. 2005, 50, 1337-1350. [CrossRef]

70. Sabater-Liesa, L.; Montemurro, N.; Font, C.; Ginebreda, A.; González-Trujillo, J.D.; Mingorance, N.; Pérez, S.; Barceló, $\mathrm{D}$. The response patterns of stream biofilms to urban sewage change with exposure time and dilution. Sci. Total Environ. 2019, 674, 401-411. [CrossRef]

71. Ameziane, T.; Garabetian, F.; Dalger, D.; Sauvage, S.; Dauta, A.; Capblanq, J. Epilithic biomass in a large gravel-bed river (the Garonne, France): A manifestation of eutrophication? River Res. Appl. 2002, 18, 343-354. [CrossRef]

72. Colls, M.; Timoner, X.; Font, C.; Sabater, S.; Acuña, V. Effects of Duration, Frequency, and Severity of the Non-flow Period on Stream Biofilm Metabolism. Ecosystems 2019, 1-13. [CrossRef] 
73. Godillot, R.; Caussade, B.; Améziane, T.; Capblanq, J. On periphyton-flow mutual influences. J. Hydrol. Res. 2001, 39, 227-239. [CrossRef]

74. Huang, W.; Liu, X.; Peng, W.; Wu, L.; Yano, S.; Zhang, J.; Zhao, F. Periphyton and ecosystem metabolism as indicators of river ecosystem response to environmental flow restoration in a flow-reduced river. Ecol. Indic. 2018, 92, 394-401. [CrossRef]

75. Romaní, A.M.; Sabater, S. Effect of primary producers of the heterotrophic metabolism of a stream biofiln. Freshw. Biol. 1999, 41, 729-736. [CrossRef]

76. Rier, S.T.; Stevenson, R.J. Effects of light, dissolved organic carbon, and inorganic nutrients on the relationship between algae and heterotrophic bacteria in stream periphyton. Hydrobiologia 2002, 489, 179-184. [CrossRef]

77. Wagner, K.; Bengtsson, K.M.; Findlay, R.H.; Battin, T.J.; Ulseth, A.J. High light intensity mediates a shift from allochthonous to autochthonous carbon use in phototrophic stream biofilms. J. Geophys. Res. Biogeosci. 2017, 122, 1806-1820. [CrossRef]

78. Genin, S.N.; Aitchison, J.S.; Allen, D.G. Design of algal film photobioreactors: Material surface energy effects on algal film productivity, colonization and lipid content. Bioresour. Technol. 2014, 155, 136-143. [CrossRef]

(C) 2019 by the authors. Licensee MDPI, Basel, Switzerland. This article is an open access article distributed under the terms and conditions of the Creative Commons Attribution (CC BY) license (http://creativecommons.org/licenses/by/4.0/). 